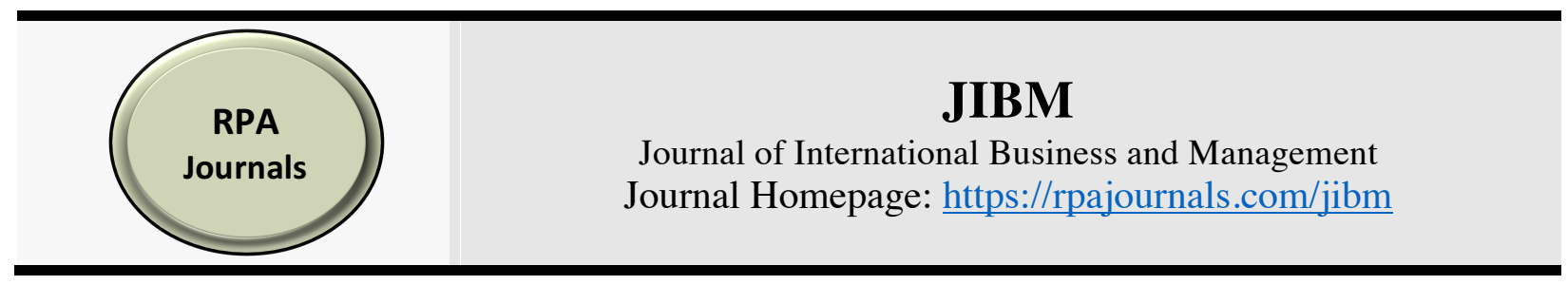

\title{
The Impact of High Credit Risk in Financing Small Scale Businesses in Ghana: The Case of Universal Merchant Bank
}

\author{
Maxwell Dela Yao Gakpo ${ }^{1 *}$ \\ Samuel Romulus ${ }^{2}$ \\ John Kofi Mensah ${ }^{3}$ \\ University College of Management Studies, Accra, Ghana ${ }^{{ }^{*}}$ \\ Ecobank Ghana, Ridge, Accra, Ghana ${ }^{2}$ \\ Agricultural Development Bank, Accra, Ghana ${ }^{3}$
}

\begin{abstract}
This descriptive study evaluated the challenges and prospects associated with reducing high risk factors associated with financing small and medium scale enterprises (SMEs) in Ghana with the search light on the operations of Universal Merchant Bank. The study adopted the cross-sectional research design to conduct the study and this enabled the researcher to solicit information from both customers and officials of Universal Merchant Bank for their views. Purposive sampling technique was used to select officials of the bank. The study employed qualitative research analytical tools which focused on the use of tables, pie charts, percentages and bar charts in analyzing and interpreting the data captured from the field. The study found out that although SMEs constitute the engine of growth in the Ghanaian economy and therefore ought to be financially fluid, banks often discriminate against them in their loan investment portfolios owing to serious financial injuries often sustained in the process of providing the badly needed funds. Numerous challenges associated with financing SMEs in Ghana stretch from deliberate efforts at misapplying solicited short-term funds for capital expenditure such as buying land or vehicles which results into repayment challenges. The study noted with surprise that unfair trade practices especially dumping of cheap Chinese products on the local market also result in poor sales for the SMEs leading to difficulty in honoring structured loan repayment schedules. The study made key recommendations.
\end{abstract}

Keywords: Credit Risk, Financial Management, Small and Medium Enterprises

*Corresponding author: Maxwell Dela Yao Gakpo; Email: delayaogakpo@gmail.com

DOI: https://doi.org/10.37227/JIBM-2020-04-123/

\section{Introduction}

Small and Medium Enterprises (SMEs) have been described in many circles as socioeconomic development tools. In Ghana, SMEs have been the catalyst for poverty reduction and the engine of growth of the economy. Though an all-important sector of the economy, which requires intentional policies to support its growth, however, lacks the necessary supports from the formal financial sector. Many banks operating in the country complain of 
high-risk factors associated with lending to the SMEs, hence shy away from funding anything described as SME. According to Essien (2005), most of the huge bad debts or nonperforming assets sticking on the books of the financial institutions emanated from their association with SMEs and therefore some banks have decided to discriminate against SMEs in their investment in loan portfolio yet the million dollar question is how can the banks sideline the SMEs sector in their financial intermediation role? How then will the economy of Ghana improve? Perhaps, what the banks need to do is to improve upon their credit risk management skills. On the global scale, the financial services environment faces various forms of risk, in their endeavors at achieving their targets and objectives. The inability to manage these risks can cause irreparable damage.

Credit risk, according to Berger (2005) is a potential loss sustained by a lender as a result of refusal or inability or borrower or counterparty to pay what is owed in full and on time in respect of anticipated payments. Such loan defaults could jeopardize the very existence of these banks if elaborate risk management practices were not put in place. According to Kannan and Thangavel (2005) the last twenty years have been marked by substantial financial deregulation. Accompanying this deregulation has been a plethora of methodologies for managing the risks/rewards created by this deregulation. Over the past decade or so, Jorion (2007) claimed that the markets have seen one debacle after another, each of which has brought its own set of lessons and from many of which the markets still need to learn. Enterprise risk management is about optimizing the process with which risks are taken and managed. It has become a burning issue because organizations have started suffering huge losses often from the risks they never should have taken in the first place. Ghanaian banks as indicated above have had their fair share of losses emanating from operational risk factors especially credit risk. Not much study has been conducted within the sub-region on this subject area and therefore literature for taking remedial measures is very scanty. Accordingly, the study attempted to critically evaluate the credit risk management practices of Universal Commercial Banks and appropriately recommended some remedial actions.

\section{Literature Review}

This section reviews existing literature on credit risk theory, portfolio theory and liquidity theory of credit. The section further reviewed extant literature on conceptual framework on credit risk management practices in banking.

\section{Credit Risk Theory}

Credit risk theory according to Crosbie et al., (2003) hinged on three quantitative approaches for assessing risk namely reduced form appraisal, structural approach and incomplete information approach. The credit risk theory was introduced by Melton (1974) and was earlier named structural theory. The theory postulates that the deterioration in asset's value is caused by its evolution modeled by some kind of diffusion process with certain constant parameters. Much of their default depends upon certain variables relating to specific issues. Longstaff and Schwartz (1995) indicated that an evolution of this category is marked by loss of asset which is modeled on the loss conditional to default which is exogenously specific. With such models the source explains that the default can occur throughout all the life of a corporate bond and not only on maturity. 


\section{Portfolio Theory}

The portfolio theory of investment endeavors to explain the idea that all investors logically will want to maximize their return on investment and this also mandates investors to play it safe and put in place structures that should minimize any trace of losses on investment. Markowitz (1952) criticized the widely used portfolio theory especially taking cognizance of its connotations in behavioral economics. Although the theory itself has won a lot of awards including noble price, the challenge to it stems for the fact that it is often overstretched to the disadvantage of the underprivileged or down trodden. Investors seek to maximum their return so much so that cost of production is adversely affected and often passed on the prices of goods and services (Madura, 2008). The theory itself entered the public domain in the 1950s and firmed up through the 1970s under the auspices of mathematical modeling of finance. The latter exacerbated the regime of a sea of criticism against the portfolio theory on investment. Sprout (1998) for instance criticized the theory because in his view it failed to follow the Gaussian distribution pattern or any kind of symmetric distribution which exhibited relationship between assets.

\section{Liquidity Theory of Credit}

The liquidity theory of credit as initiated by Emery (1984) seems to suggest that credit rationed firms employ more business funds than those with average access to institutions in the financial services environment. The cardinal point here presupposes that when company is cash strapped, decision by a lender to offer business credit could compensation for the apparent drop in operating funds. In keeping with these ideas, companies in the lending business do present good liquidity or can obtain funds from the capital market for on-lending to those that are less endowed or credit rationed. Some empirical studies have been conducted to support this liquidity theory of credit. Nielsen (2002) for instance employed small firms in the study of needy companies and noted that when small firms suffocate financially, then their propensity to attract trade credit from various category of lenders increase. Petersen \& Rajan (1997) also found out that financially unconstraint companies showed little interest in demanding trade credit and rather will wish to lend than access it. This therefore exhibits some negative correlation between trade credit demand group and those ready to offer.

\section{Conceptual Framework on Credit Risk Management}

According to Froot et al., (2003), risks exist because entities, companies, and organizations have "assets" of a material or immaterial nature that could be subject to damage that has consequences on the entity in question. Oldfield and Santomero (2007) indicated that, the principal concept used in credit risk management is assets, a term often used in the field of financial institutions to refer to loans to customers, deposits with other banks, as well as security with industry regulators, etc. In very general terms, an asset can be defined as anything that could be of value or importance to the entity. Conti and Mauri (2008) submitted that, clearly, risks (and their consequences) differ depending on what type of damage occurs. Generally speaking; a risk (as opposed to an observation or certainty) exists only if an uncertain action or event happens that leads to the occurrence of that risk - in other words the damage of the asset in question. Risk evaluations must include an assessment of how likely this action or event is to occur. According to Anam et al., (2012) credit risk is the potential that a bank borrower/counterparty fails to meet the obligations on agreed terms. There is always scope for the borrower to default from his commitments for one or the other reason resulting in crystallization of credit risk to the bank. These losses could take the form 
outright default or alternatively, losses from changes in portfolio value arising from actual or perceived deterioration in credit quality that is short of default. Tapiero (2004) asserted that, credit risk is inherent to the business of lending funds to the operations linked closely to market risk variables. Robinson (2001) noted that, credit risk consists of primarily two components, viz Quantity of risk, which is nothing but the outstanding loan balance as on the date of default and the quality of risk, viz, the severity of loss defined by both probability of default as reduced by the recoveries that could be made in the event of default. Thus, credit risk is a combined outcome of Default Risk and Exposure Risk. Altman (1993) believed that, the elements of Credit Risk are Portfolio risk comprising Concentration Risk as well as Intrinsic Risk and Transaction Risk comprising migration and down gradation risk as well as default risk. At the transaction level, credit ratings are useful measures of evaluating credit risk that is prevalent across the entire organization where treasury and credit functions are handled. Portfolio analysis, help in identifying concentration of credit risk, default or migration statistics, recovery data, etc. In general, Saunders (1996) noted that, default is not an abrupt process to happen suddenly and past experience dictates that, more often than not, borrower's credit worthiness and asset quality declines gradually, which is otherwise known as migration. Default is an extreme event of credit migration. Off balance sheet exposures such as foreign exchange forward contracts, swaps options etc are classified into three broad categories such as Full Risk, Medium Risk and Low risk and then translated into risk neighed assets through a conversion factor and summed up. Rouse (2004) explained that the management of credit risk includes a) measurement through credit rating or scoring, b) quantification through estimate of expected loan losses, c) pricing on a scientific basis and d) controlling through effective loan review mechanism and portfolio management.

\section{Methodology}

The study adopted the cross-section research design within qualitative research approach to allow the researcher to solicit information from both customers and officials of Universal Merchant Bank. Qualitative research approaches helped in planning and implementing the activities of the study. Qualitative research according to Strauss and Corbin (2000) is the collecting, analysis and interpreting of data by observing what people say or do which come under the concept of phenomenology. In the opinion of Zikmund and Babin (2010), phenomenology represents a philosophical approach to studying human experiences based on the idea that human experience itself is inherently subjective and determined by the context in which people live. In the view of Zikmund and Babin (2010), when studies involve picking data and interpreting, then some amount of subjectivity come into play which calls for qualitative analysis. The study targeted Universal Merchant Bank Ghana (UMB) one of the reputable universal banks in the country. The head office of Universal Merchant Bank (UMB) and four branches in Accra Business District were the targeted branches for the study sample. The sample distribution is as follows:

Table 3.1: Distribution of Respondent

\begin{tabular}{llll}
\hline Branches & Bank Officials & Customers & Total \\
\hline Head office & 20 & 20 & 40 \\
Adabraka & 5 & 10 & 15 \\
Kaneshie & 5 & 10 & 15 \\
North Industrial Area (NIA) & 5 & 10 & 15 \\
Abeka & 5 & 10 & 15 \\
\hline Total & 40 & 60 & 100 \\
\hline
\end{tabular}


Customers of the bank ply their trade in various sectors of the economy, consequently care was exercised to ensure that retailers, manufactures, civil servants, public servants, service providers, technocrats and other professionals were represented in their sample size of sixty (60). Fortunately, Universal Merchant Bank arranges its customer base according to business type and therefore these business groups would constitute strata (or singular stratum) from which random sampling technique was employed to select the sample size. It can therefore be said that random sampling was laced up with stratified sampling technique to arrive at the required size of sixty (60) for the customers. In the case of the sample size of forty (40) for bank officers, purposive sampling technique was adopted to directly approach senior officials and management members whose job entail credit analysis and risk management. A questionnaire was used to collect data from the two categories of respondents. The questionnaire technique granted the respondents the necessary flexibility required to enable them answer the questions at their convenient period. The questionnaire for customers of the banks examines the demographic features of the respondents before probing into issues relating to their risk factors associated with financing SMEs in Ghana. The types of bank credits solicited by customers and the benefits derived from these facilities were all evaluated. Customer respondents were also asked to indicate reason why some of them failed to repay loans as well as steps that should be taken to ensure that loans and interest return safely. Questionnaire for the bank officials explored ways of making lending much safer. It also found out how to beef up monitoring and control so as to retrieve all loans and their interest thereby registering a better return on the shareholders' investment.

\section{Data Presentation and Analysis}

This section presents the analysis of data captured from the field study together with their interpretation and discussion of findings. It begins by discussing the demographic data on the respondents. The respondents' demographic features are gender, age range, marital status, and highest academic qualifications (see table 4.1 to 4.4 ).

Table 4.1: Frequency Distribution Table on the Gender of Respondents

\begin{tabular}{lllll}
\hline \multirow{2}{*}{ Gender } & Customer & \multicolumn{3}{c}{ Bank Officials } \\
& Frequency & Percentage $\%$ & Frequency & Percentage \% \\
\hline \multirow{3}{*}{ Male } & & & & \\
Female & 29 & 51.5 & 18 & 19.6 \\
\hline Total & 25 & 27.2 & 20 & 21.7 \\
\hline
\end{tabular}

Source: Field Data (2017)

In table 4.1, it can be deduced that the study had the compliments of 92 respondents out of which 54 are customer respondents and 38 bank respondents. Table 4.1 also shows that out of the 38 bank officials in the entire study sample size of 92, $20(21.7 \%)$ are females while $18(19.6 \%)$ respondents are males. With the customer respondents $31.5 \%$ respondents are male of which $27.2 \%$ are female. The fact that the male customer-respondents outnumber the females confirm the findings by Aryeetey et al (2002) that, the propensity to register businesses in Ghana tilts in favor of men than their female counterparts. Table 4.1 also reveals that the sample of bank officers is slightly higher than the male thereby confirming 
the statement by CIB newsletter (2007) that banks in the country have more female employees than their opposite sex workers.

\section{Age Range of Respondents}

The trend of the age range of the respondents is shown in table 4.2.

Table 4.2: Frequency Table on the Age Range of Respondents

\begin{tabular}{lllll}
\hline Age Range & Customer & & \multicolumn{2}{c}{ Bank Officials } \\
& Frequency & Percentage & Frequency & Percentage \\
\hline $21-30$ & 5 & 5.4 & 14 & 15.2 \\
$31-40$ & 20 & 21.7 & 16 & 17.4 \\
$41-50$ & 15 & 16.3 & 5 & 5.4 \\
$51-60$ & 10 & 10.9 & 3 & 3.3 \\
Above 60 years & 4 & 4.4 & - & - \\
\hline Total & 54 & 58.7 & 38 & 41.3 \\
\hline
\end{tabular}

Source: Field Data (2017)

In table 4.2, 29 out of 54 customer respondents constituting 53.7 percent are aged above 40 years whereas in the case of the bank officials only 8 of their 38 sample size $(21.0 \%)$ are above 40 years. This shows that the banks are engaging much younger professionals to help them contain the increasingly stiff competition in the industry. According to Addaih (2008) with ICT changing the face of banking, it behooves on management of financial institutions to hire young IT professionals to help strategize the direction of their organization.

\section{Respondents Highest Academic Qualification}

This section presents data on the highest qualification of respondents. The data is presented in table 4.3.

Table 4.3: Frequency Table showing the Highest Qualification of Respondents

\begin{tabular}{lllll}
\hline Type of Qualification & Customer & & \multicolumn{2}{c}{ Bank Officials } \\
& Frequency & Percentage & Frequency & Percentage \\
\hline MSLC/ BECE & 6 & 6.5 & - & - \\
GCE 'O'/'A' Level & 10 & 10.9 & - & - \\
Diploma/ HND & 18 & 19.7 & 3 & 3.3 \\
First Degree & 12 & 13.0 & 12 & 13.0 \\
Masters Degree & 4 & 4.3 & 10 & 10.9 \\
First degree \& professional & 4 & 4.3 & 10 & 10.9 \\
Master degree \& professional & - & - & 5 & 5.4 \\
\hline Total & 54 & 58.7 & 38 & 41.3 \\
\hline
\end{tabular}

Source: Field Data (2017)

In table 4.3, 19.7\% customer-respondents have various shades of Diplomas and Higher National Diplomas while $13.0 \%$ customers possess first degree qualifications. $10.9 \%$ customer-respondents wield General Certificate of Education (GCE) ' $O$ ' and ' $A$ ' Levels while $6.5 \%$ also have basic school leaving certificate such as MSLC and BECE. 4.3\% customer-respondents have their master degree while further $4.3 \%$ customer respondents also have masters in addition to such professional qualifications as CIM, ACCA, BL (Law) etc. 
Twelve (13\%) bank respondents possess the first degree with 10(10.9\%) having their masters degrees. $10.9 \%$ bank respondents possess both the first degree with the banking professional qualification where $5.4 \%$ bank officials also have their master's degrees in addition to other professional qualification such as CIMA, CA $(\mathrm{GH}), \mathrm{CIB}$, professional qualification of the Institute of Engineers. It is really difficult to understand the role of a civil engineer in a banking environment. Perhaps he is in-charge of the Estate or general services department of the bank. 3.3\% bank respondents have HND and other types of Diploma. The analysis above shows that 38 out of the 54 (70.4\%) customer respondents have 'tasted' tertiary education and this finding has been corroborated by Mensah (2004) who concluded that a lot more graduates of tertiary institutions are entering into the private sector and that Ghana is likely to witness a lot more sophisticated private sector than existed some decades ago.

According to Otabil (2008) with technology 'invading' every facet of business, operators of the private sector will have no option but to seek higher qualifications especially in ICT and e-commerce so as to enable them integrate fully into global business. It was therefore gratifying when Mensah (2004) declared that the Trade and Industry Ministry was liaising with other government agencies to ensure that the necessary structures were created to shore up interest of the operators of the private sector in the ICT literacy. Adu-Mante (2007) also advised his fellow members of the Association of Ghana Industries (AGI) to endeavor to be abreast with current wind of change being precipitated by the era of computerization. He explained that there are a good number of software especially Enterprise Resource Planning (ERP) that could help introduce efficiency in use of resources thereby cutting cost and increasing profit to improve the prospects of their businesses.

\section{Marital Status of Respondents}

This section provides data on the marital status of the respondents. The data is presented in table 4.4.

Table 4.4: Frequency Table Showing the Marital Status of Respondents

\begin{tabular}{lcccc}
\hline Marital Status & \multicolumn{2}{c}{ Customers } & \multicolumn{2}{c}{ Bank Officials } \\
\hline & Frequency & Percentage (\%) & Frequency & Percentage (\%) \\
\hline Married & 28 & 30.4 & 30 & 32.6 \\
Unmarried & 12 & 13.0 & 3 & 3.3 \\
Divorced & 9 & 9.8 & 3 & 3.3 \\
Widow/widower & 5 & 5.5 & 2 & 2.2 \\
\hline Total & 54 & 58.7 & 38 & 41.8 \\
\hline
\end{tabular}

Source: Field Data (2017)

Table 4.4 shows that $28(30.4 \%)$ customer respondents are married, $9(9.8 \%)$ of them are divorced while $12(13 \%)$ of these customer respondents are unmarried. $5(5.5 \%)$ customer respondents have lost their partners. In case of the bank officials $30(32.6 \%)$ respondents are married. $3(3.3 \%)$ are unmarried while a further $3(3.3 \%)$ have come out of their wedlock's. Two of these bank officials are widows. The analysis above points to the fact the 30 out of the $38(79 \%)$ of the bank officials are happily married as against 28 out of $54(51.8 \%)$ customer respondents who are fully married. Could the difference between these indicators on marriage suggest that bank officials have easy access for soft loans and other grants so they have little difficulty in tightening the knot at the altar as opposed to a private enterprise operation that really has to struggle to save towards marrying? Perhaps this is a subject for another study. 


\section{What are the high risk factors associated with SMEs in Ghana?}

In consonance with research objective one, this segment analyzes responses obtained from both bank officials and customers in relation to issues on high risk factors associated with SMEs in Ghana. It begins with responses from bank officials with 38 respondents.

\section{Bank officials' Views on Product offered by UMB}

Presented in table 4.5 are the views from bank officials concerning products offered by the bank.

Table 4.5: Frequency Table showing Kinds of Services provided by the bank

\begin{tabular}{lccc}
\hline Types of Services & $\begin{array}{c}\text { Yes } \\
\%\end{array}$ & $\begin{array}{c}\text { No } \\
\%\end{array}$ & $\begin{array}{c}\text { No idea } \\
\%\end{array}$ \\
\hline Over-draft facilities & 100 & - & - \\
Mortgage loans & 65 & 10 & 25 \\
Personal Loans & 100 & - & - \\
Corporate Loans & 100 & - & - \\
Project Loans & 55 & 32 & 13 \\
SME Loans & 100 & - & - \\
Leasing & 60 & - & - \\
Collateral Management & 40 & 40 & 20 \\
Agric Loans & 100 & - & - \\
\hline
\end{tabular}

Source: Field Data (2017)

Table 4.5 shows that all 38 banks officials indicated that they offer overdraft facilities at their outfits. This is not surprising because according to Hester and Pierce (2002), Bank overdraft constitute one of the key areas where the bank generate revenue while at the same time helping customers to finance their expansion activities. Morsman (2003) argues that many establishments would have lost the cream of the workers as a result of frequent cash flow challenges in meeting the monthly wage bills. Such entities always rush in for overdraft facilities to accommodate salary payments and other recurrent expenditure.

According to Shapiro (2006) overdrafts are simply lines of credit against which drafts cheques can be drawn (written) up to a specified maximum amount. Allan Shapiro explains further that these overdraft lines are often extended and expanded year after year, thus providing in effect a form of medium-term financing. Interest according to Madura (2008) is paid only on the debt balance. Twenty five out of the thirty eight bank officials representing 65 percent indicated that Mortgage loans are available but are conducted through accredited home finance companies. $25 \%$ bank respondents indicated that they had no idea whether the facilities existed at their branch office or not. Four $(10 \%)$ respondents mentioned emphatically that they don't have the mortgage facility at their end.

All $38(100 \%)$ respondents indicated that they give personal loans at their outfit. All officials also said their branches dish out corporate loans to reputable companies. 55\% respondents from the bank spoke of project loans as one of the products they offer. $32 \%$ respondents indicated that the facility did not exist at their end whereas $13 \%$ respondents did 
not have any idea whether the product existed or not. All 38 respondents $(100 \%)$ stated that their outfits give SME loans. $60 \%$ respondents indicated that leasing is available at their outfit while $40 \%$ appeared to lack knowledge about the availability of any such product at their work place. $40 \%$ respondents indicated that collateral management is one of the products they offer while a further $40 \%$ respondent's product is not available at their outfit. $20 \%$ respondents indicated that they had no idea whether the product existed or not. All 38 respondents emphasize that their outfits deal in Agricultural loans.

\section{Bank officials' Views on Reasons for Declining Loan Applications by Bank}

The study wanted to know why the bank declines some applications for loans. The findings have been depicted on figure 4.1 .

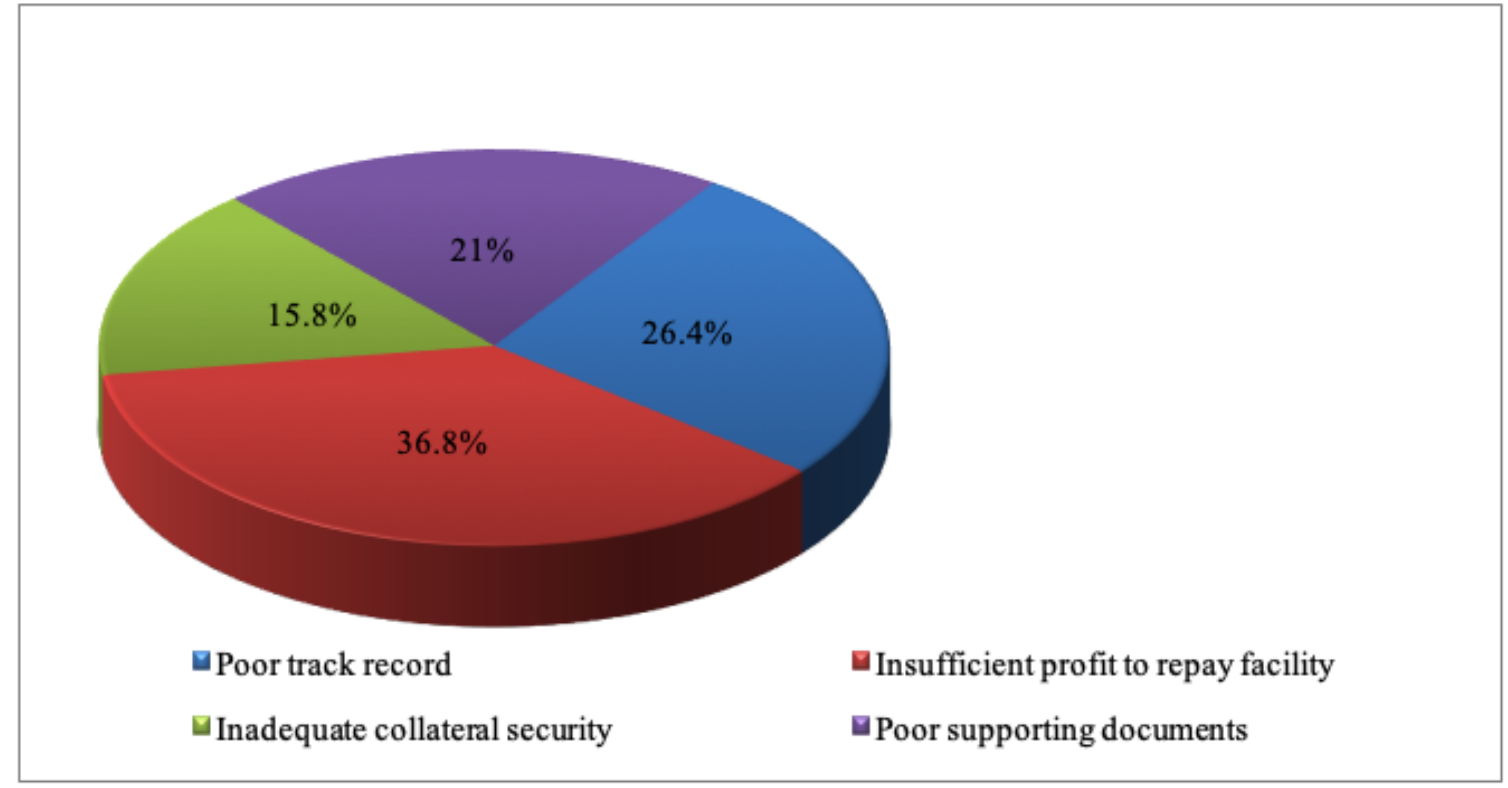

Figure 4.1 Pie chart showing reasons why banks declines loans applications

Source: Field Data (2017)

In figure 4.1, 36.8\% bank respondents indicated that loans applications are often declined because projected profits appear inadequate to accommodate the repayment of the facility and the attendant interest. $26.4 \%$ respondents also pointed at the poor track record which could jeopardize the prospect of the business. In the opinion of Rodriguez and Carter (2004) Advances to customers from 50 to 70 percent of total assets of banks and as the backbone of the banking structure, credit officers ought to be cautious about loans that have the propensity of going bad especially when health check of the business suggest lack of experience of managers or insufficient profit to repay facility. $21.0 \%$ respondents from the bank also indicated that the bank often decline loan application from customers with poor supporting documents. Diamond (2001) note that where loan applications have insufficient records to enable meaningful assessment of the business prospects, it is not prudent granting facilities. He goes on to say that financial statements must go in tandem with the management accounts for any constructive assessment of the company to be made. $15.8 \%$ respondents pointed out loan seekers often fail to produce adequate security for the facility and this result in the credit committee's decision to decline the application. 
Bank officials' Views on Reasons for Loan Default (High Risk Factor in Lending)

Reasons given for loan default can be dichotomized into internal factors and external factors.

Table 4.6 Frequency Table on Internal Factors that precipitate Bad Debt

\begin{tabular}{lcc}
\hline Internal Reasons for Loan Default & $\begin{array}{c}\text { Frequency } \\
\text { (Out of 38) }\end{array}$ & $\begin{array}{c}\text { Percent } \\
(\%)\end{array}$ \\
\hline Diversion of funds for expansion & 36 & 95 \\
Diversification of business & 34 & 89.5 \\
Modernization of business & 31 & 81.4 \\
Taking up new projects & 33 & 86.8 \\
Helping to promote associated business & 29 & 76.3 \\
Time or cost overrun during the implementation of & 28 & 73.7 \\
project & 34 & 89.5 \\
Business i.e. product or marketing failure & 35 & 92.1 \\
Management inefficiency & 33 & 86.8 \\
Slackness in Credit management and monitoring & 29 & 76.3 \\
Inappropriate technology or technical problem & 25 & 65.8 \\
Lack of co-ordination among lenders & & \\
\hline
\end{tabular}

Source: Field Data (2017)

Table 4.6 shows that $36(95 \%)$ respondents from the bank pointed out that loan default often reasons from borrowers trying to divert funds meant for expansion. Essien (2005) explained that customers who endeavor to divert funds often go into new areas where they lack the requisite expertise and therefore the expected revenues are not achieved thereby sensing their limitations in repayment of facility. A total of $30(89.5 \%)$ respondents also mentioned the fact that in an attempt to add on other product line through business diversification the funds get locked up and, in the process, customers experience cash flow challenges which translate into default in repayment. Also, $31(81.4 \%)$ respondents pointed out that in an attempt to modernize their businesses, customer use short-time funds solicited from the bank to finance such long-term projects and this logically results in cash flow problem and therefore inability to repay loans and their interest. $33(86.8 \%)$ respondents mentioned the fact that sometimes customers use funds solicited for new projects only to realize that expectation cannot be met resulting in problems with repayment of the facilities. $29(76.3 \%)$ respondents pointed out that funds secured from the bank for expanding existing business are rather used to promote associated businesses. 28 (73.7\%) respondents mentioned time or cost overrun during the implementation of projects leading to cash flow challenges. According to Hester (2001), project time and cost overrun often generate controversy between the contractor and the client leading to delay in payment for service rendered. This often results in disruption of the repayment schedule for loans contracted to execute the project. $34(89.5 \%)$ respondents mentioned business failure especially, poor product showing on the market or inappropriate marketing strategies which do not position goods properly at the market place. $35(92.1 \%)$ respondents mentioned management inefficiency as a key component in loan default. Silber (2008) noted that financial institutions 
should endeavor to establish the managerial competence through a very convincing track record prior to allowing a draw down on facilities. 33 (86.8\%) respondents categorically spoke of the slackness in credit management and monitoring as a key factor that precipitates loan default. Dyer (2004) indicated in uncertain terms that lenders who cannot monitor borrower's activities closely are likely to incur huge non-performing assets. 29 (76.3\%) respondents spoke of inappropriate technology or technical problem which could result in poor products. Salmon Brothers (1999) maintained that manufacturers with inappropriate technology are likely to be crowded out of the market. This means firms should always ensure that they assemble state-of-the-Art equipments so as to compete effectively on the market. 25 (65.8\%) respondents mentioned lack of co-ordination among lenders as another factor that breeds bad loans. Bank officials' Views on External Factors that cause loan default (High Risk Factor in Lending) External factors that were listed by bank officials to be responsible for loan default have been featured in Figure 4.2.

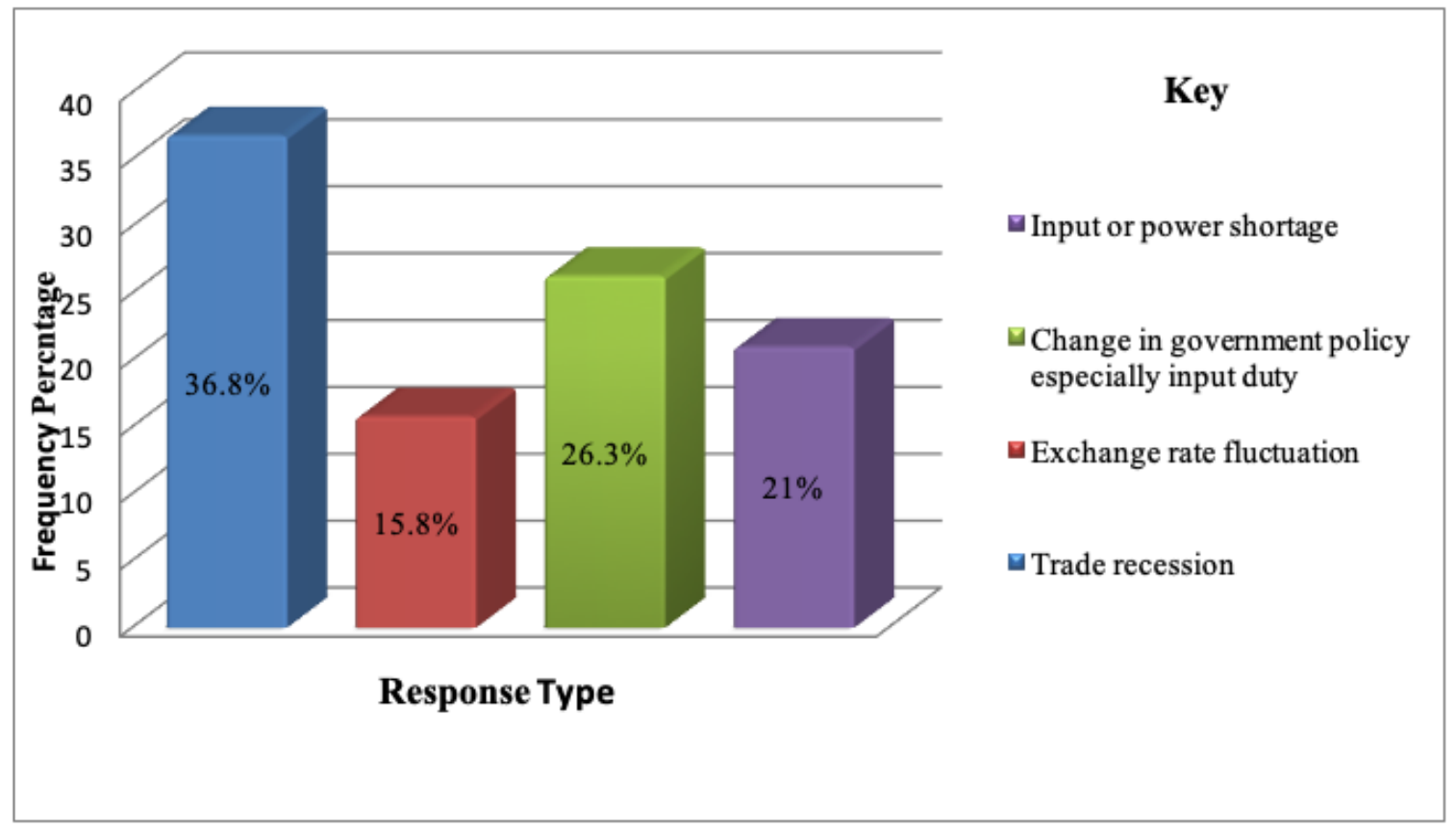

Figure 4.2. Bar-chart show external factors that cause loan default. Source: Field Data (2017)

Figure 4.2 shows that 14 out of the 38 bank respondents constituting $36.8 \%$ pointed out that shortage of external inputs especially power outages disrupt customer's production schedule leading to reduction in volume of sales and as a consequence adversely affecting the repayment schedule agreed with the bank. $26.3 \%$ respondent mentioned exchange rate fluctuations as another factor which erode customers funds thereby creating cash flow problems. $21.0 \%$ respondents pointed out that general trade recession often has harsh impact on trading activities of customers leading to breach of repayment arrangements agreed with the lender. $15.8 \%$ respondents also spoke of change in government policy especially on import duty which has the effect of increasing customers' cost of operations thereby reserving inadequate funds to honour loan repayment schedule with the banks. 


\section{Bank officials' Views on Prospects for Reducing Credit Risk (Bad debts)}

The study sought to understand the prospects for banks being able to reduce high risk associated with financing SMEs; the results have been featured in Table 4.7.

Table 4.7: Frequency Table Showing the Bank's Prospects for reducing bad debts

\begin{tabular}{lcc}
\hline Prospects for reducing Bad Debts & $\begin{array}{c}\text { Frequency } \\
\text { (out of 38) }\end{array}$ & Percent (\%) \\
\hline Improvement of working capital & 38 & 100 \\
Granting of more loans to businesses & 26 & 68.4 \\
Granting of more loans to individual & 30 & 78.9 \\
Businesses expand to pay more taxes & 32 & 84.2 \\
Shareholders receive better return on investment & 36 & 94.7 \\
Banks employees are better remunerated & 34 & 89.5 \\
\hline
\end{tabular}

Source: Field Data (2017)

In table 4.7, it can be gathered that all 38 respondents from the bank i.e. $100 \%$ indicate that if the banks are able to drastically reduce bad debt or credit risk associated with financing small businesses, their working capital base will be greatly enhanced. From table 4.7, 36 (94.7\%) respondents noted that another prospect for reducing bad debt drastically involves the fact that shareholders will receive better return on the investment because banks will grant more loans to expand the scope of their business and in the process make more profit to declare larger dividends. The study shows that 34 $(89.5 \%)$ respondents that when banks are able to fully recoup their loans and attendant interest, much profit will be made to strengthen emoluments paid to employees. $32(84.2 \%)$ respondents mentioned that the reduction in bad debt as a result of improvement in credit risk management, will result in expansion in businesses thereby making more profit to pay more taxes to the state. $30(78.9 \%)$ respondents submitted that by recovering almost all loans, banks will be in a better position to grant more consumer loans to individuals to better their living standards. In the view of $26(68.4 \%)$ respondents, reduction in bad debt or in high credit risk will generally result in the banks granting more loans to business.

Customers' Views on items required prior to considering loan application by the Bank The researcher wanted to have an idea from customers about items required by the bank before considering loan application. The findings have been featured in Table 4.8.

Table 4.8 Frequency Table showing views on items required for loan application

\begin{tabular}{lcc}
\hline Business experience & $\begin{array}{c}\text { Frequency } \\
\text { (out of 54) }\end{array}$ & $\begin{array}{c}\text { Percentage } \\
(\%)\end{array}$ \\
\hline Business experience & 52 & 96.3 \\
Projected cash flow & 49 & 90.7 \\
Financial Statement & 42 & 77.8 \\
At least 6 months of successful operation of Account & 47 & 87.0 \\
\hline
\end{tabular}

Source: Field Data (2017) 
Table 4.8 shows that $52(96.3 \%)$ of the respondents indicated that the bank requires business experience as one of the requirements for considering loan applications. Dyer (2004) explained that it's suicidal to lend to an inexperienced entrepreneur. This is because the funds are likely to go down the drain. $49(90.7 \%)$ respondents mentioned projected cash flow as another pre-requisite document that customers must submit prior to being considered for loan purposes. Also, 87\% represent respondent's view of successful operation of customers account for at least six months before being considered for a loan facility. $42(77.8 \%)$ respondents mentioned financial statement is another requirement for accessing loans from the bank. According to Dyer (2004) financial statements provides a historic record of the financial performance of an enterprise and this helps the bank to evaluate the realism of projection made. Madura (2008) also notes that financial statements help to determine whether projections made in the management Accounts are over ambitions or not.

\section{Customers' Views on how Loans helped customers}

The study sought to investigate how funds solicited by customers were employed. Findings have been featured in Table 4.9.

Table 4.9 Frequency Table showing Loans helped customers

\begin{tabular}{lcc}
\hline Responses Type & $\begin{array}{c}\text { Frequency } \\
\text { (out of 54) }\end{array}$ & $\begin{array}{c}\text { Percentage } \\
\text { (\%) }\end{array}$ \\
\hline Support customers working capital & 52 & 96.3 \\
Helped in paying of some debt so as to renew supply contract & 41 & 75.9 \\
Helped in meeting data to day expenses & 46 & 85.2 \\
Make extra purchases & 43 & 79.6 \\
Expand business & 48 & 88.9 \\
\hline
\end{tabular}

Source: Field Data (2017)

Table 4.9, 52 out of the 54 customer respondents constituting 96.3 percent pointed out that loans contracted from the bank enhanced their working capital bases. According to Mwaneketwe (2007) one prudent use of bank credit by Merchants is to use the fund to revamp the working capital base of the enterprise. Essien (2005) also supported this view by asserting that funds solicited for businesses purposes must eventually help to improve the operating capital of such business houses. $88.9 \%$ respondents revealed that loans contracted helped in expanding their operations. $85.2 \%$ respondents indicated that they used the bank funds to meet day to day operations of their outfits. $79.6 \%$ respondents indicated that loans solicited helped them to make extra purchases. $75.9 \%$ respondents also disclosed the fact that the loan helped them to clear some debt so as to renew supply contract. Dyer (2004) criticizes the act of borrowing to pay off old debts. He lamented over the fact that such financial outlays constitute a 'leakage' and therefore repayment is often difficult since it somehow adversely affects the operating capital.

\section{Analysis of challenges associated with managing credit risk by UMB}

In keeping with research question two, the researcher inquired from both bank and customer about the challenges associated with managing risk at the bank. Responses have been presented first in the case of the bank and second the customers. 


\section{Bank officials' Views on Challenges associated with managing credit risk}

Table 4.10 exhibits the type of constraint confronting management of UMB in managing credit risk within their outfit as portrayed by the bank officials.

Table 4.10: Frequency Table on Challenges Confronting the Bank in Retrieving Loans

\begin{tabular}{lcc}
\hline Types of Constraints & Frequency & Percentage \\
\hline Lack of market for customers & 18 & 47.4 \\
Logistical constraints & 12 & 31.6 \\
Management Interference & 8 & 21.0 \\
\hline Total & 38 & 100 \\
\hline
\end{tabular}

Source: Field Data (2017)

In table $4.10,47.4 \%$ respondents pointed out that one main challenge to retrieving loans lies with lack of market for customers. Competition is increasing getting keener at the market place so much so that retailers are not selling enough to enable them honour the repayment schedules. Adu-Mante (2007) also made a similar remark in his article on challenges with financing SMEs and stressed that the multitude of people entering the small trade business is such that sales per bank customer trader is trending downwards and for that matter leads to inability of borrowers to honour repayment schedule. From table 4.10 respondents spoke of logistical constraints as another challenge to smooth payment of loan contracted by small businesses. In his empirical review on high risk factor associated with financing small businesses, Augusto et al (2008) noted that, most banks do not have adequate vehicles to go to the field by way of monitoring the behaviour of borrowers during the loan gestation period. Derreumaux (2007) also wrote on difficulties bank face in financing small businesses in Sub-Saharan Africa and submitted that most banks had go to the field but rather prefer staying at the back office where borrowers will call on them at their discretion. DermirgucKunt (2011) also submitted that if banks can solicit assistance from the central bank and other external sources such as International Finance Corporation of the World Bank. Such soft loans can be used to procure adequate vehicles namely saloon cars, motor bikes, bicycles, point of sales terminals which can assist the bank to effectively monitor loans in the domain of the customer. On the issue of management interference acting as a challenge to reducing credit risk; table 4.10 shows that $21.0 \%$ respondents noted that some senior and top executives of the bank intervene on behalf of their friends and relatives who have defaulted on loan repayment and this have resulted in very little action been taken to correct the problem.

\section{Customer's Views on credit risk management challenges at UMB}

The study sought the opinion of customers of UMB as to why some of the default in loan repayment schedules. Their responses have been featured in table 4.11 below. 
Table 4.11 Frequency Table depicting some causes of loan default by customers

\begin{tabular}{lcc}
\hline Response Type & Frequency & Percentage \\
\hline Loans are not used for intended purpose & 17 & 31.5 \\
Customers over trade and in the process money gets locked & 15 & 27.8 \\
up & & \\
Improper monitoring leading to misuse of funds from sales & 12 & 22.2 \\
Loans used to expand fixed assets & 10 & 18.5 \\
Total & 54 & 100 \\
\hline
\end{tabular}

Source: Field data (2017)

Table 4.11 - shows that $17(31.5 \%)$ respondents indicated that borrowers often do not use loans for intended and this contributes immensely towards loan default. 15 (27.8\%) respondents mentioned overtrading as another huge source of loan default. Edwards and Millet (2005) explain that overtrading occurs when traders attempt to do too much too quickly with little funds. This often results in money being locked up in stock or inventory leading to very serious financial embarrassment. Adu-Mante (2007) advised that financial institutions to organize workshops through their business clubs to sensitize customers against overtrading. Adu-Mante (2007) suggested to business houses to discuss their expansion plans with their relationship managers rather than doing things on their own. $12(22.2 \%)$ respondents spoke of improper monitoring of loans by banks leading to misuses of sales funds by customers. An advocate of loan monitoring, Dyer (2004) argued that when loans are effectively husbanded lenders gets to know the quantum of funds gathered from sales virtually on daily basis and therefore borrowers have very little room for pleasing themselves with sales funds. $10(18.5 \%)$ respondents indicated that customers often use short-term loans especially overdraft to expand their fixed assets and therefore funds which should have gone into buying more merchandise to improve sales and by extension profit get locked up in fixed assets thereby creating repayment challenges. Shapiro (2006) noted that short-term facilities are for promoting business volume especially sales while medium to long term loans are required to finance the acquisition of fixed assets.

\section{Strategies for reducing risk factors associated with financing SMEs}

In meeting the requirement for objective three i.e. identifying strategies for reducing risk factors associated with financing SMEs, the study spoke to both bank officials and customers as presented below.

Bank officials' Views on Mechanisms for reducing risk factors associated with financing SMEs Opinion expressed by bank officials as strategies for reducing risk factors associated with financing SMEs have been presented in figure 4.3. 


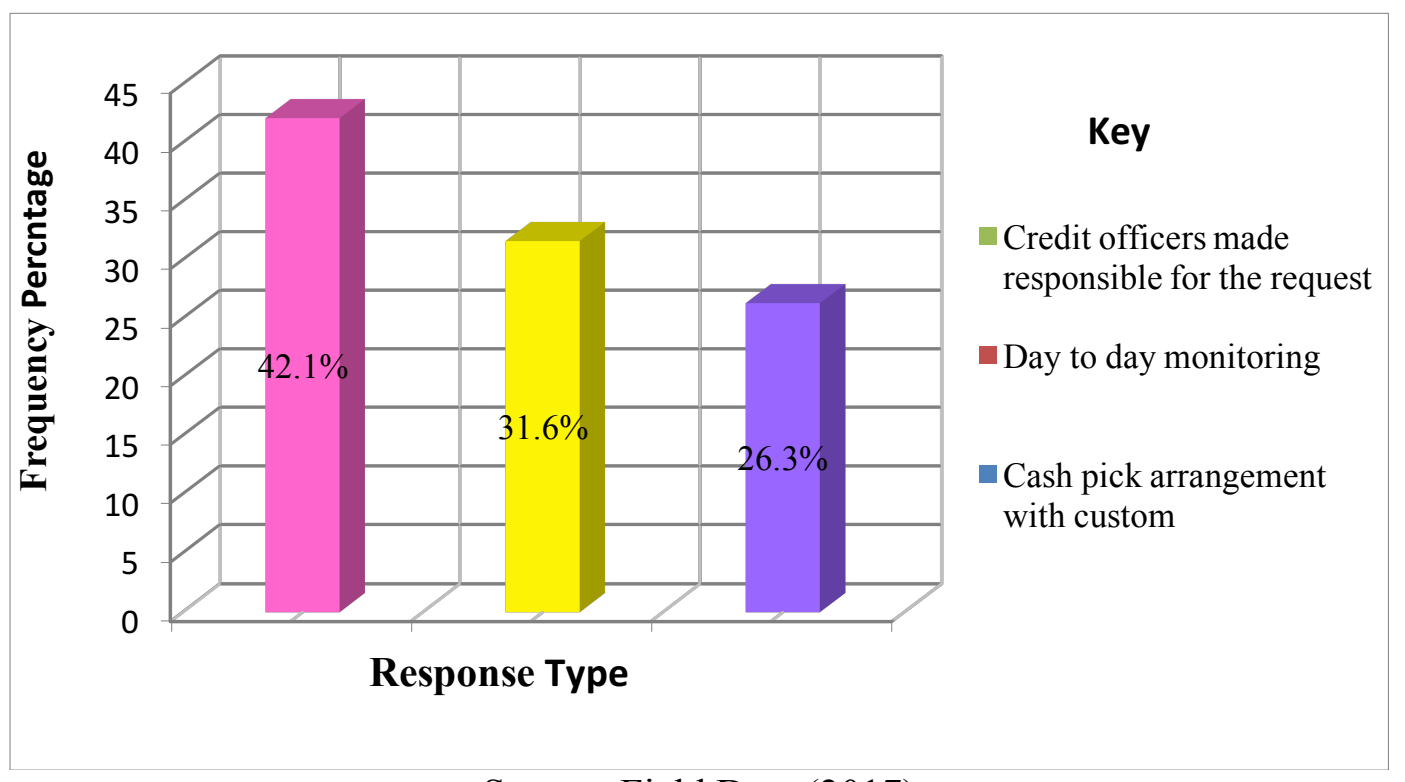

Source: Field Data (2017)

Figure 4.3 shows that $42 \%$ respondents pointed out that in order to reduce risk factors associated with granting facilities the bank has specific loan portfolios to credit officers how are supposed to report on the 'health' status of such facilities periodically. According to Dyer (2004) one sure way of minimizing non-performing assets is to strengthen relationship banking where credit officers are assigned to particular borrowers as means of monitoring the progression of such exposures. 31.6\% respondents pointed out that as a protectionist measure the bank has put in place a strategy to monitor loans given out on day to day basis. $26.3 \%$ respondents mentioned another innovative strategy which has to do with cash picking arrangements with customers.

\section{Customers' views on strategies for reducing credit risk at Universal Merchant Bank}

Presented in figure 4.4 are views on customers in respect of strategies for reducing credit risk at $\mathrm{UMB}$

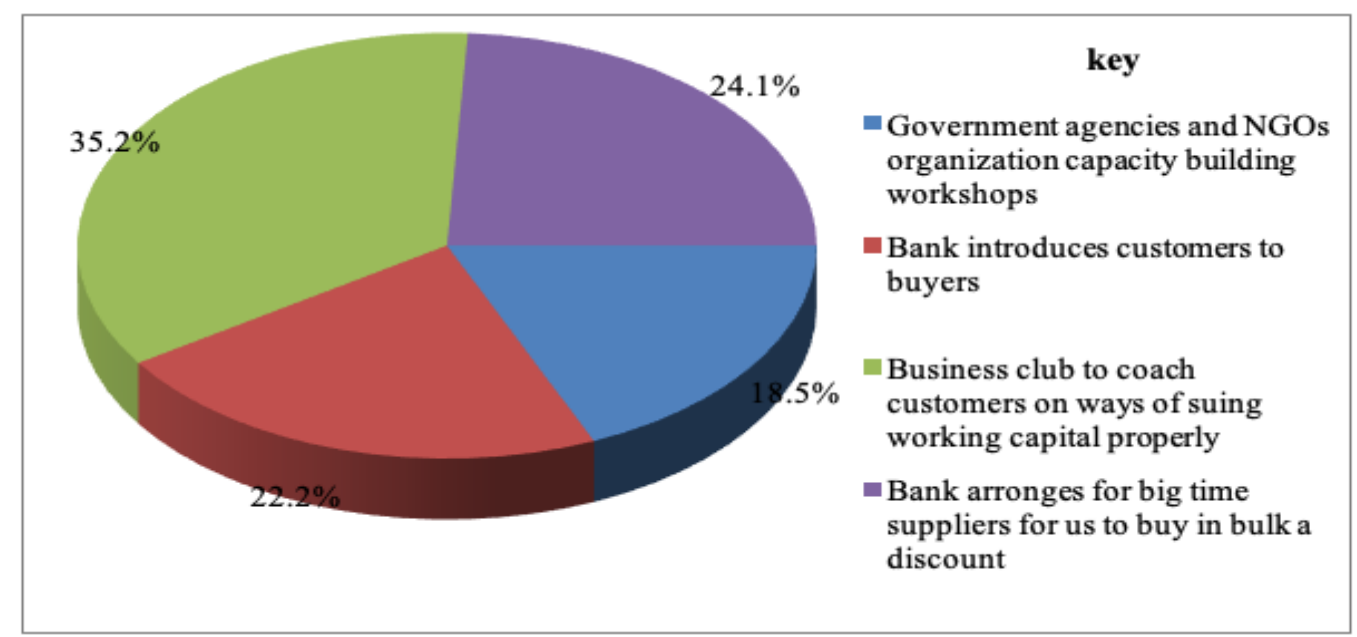

Figure 4.4. Pie-chart showing ways by which bank helps to employ loans successfully Source: Field Data (2017) 
Figure 4.4 shows that $35.2 \%$ respondents pointed out that their bank has a business club which periodically organizes workshops to sensitize them on modern methods of effectively managing working capital. Mwaneketwe (2007) corroborated this view that commercial banks with business clubs are really doing mutually beneficial business with their customers. Mwaneketwe (2007) explained that Barclays bank organizes trips to the Far East especially China for its business club members to meet big time manufacturers who are able to relate with the bank's customers in a more positive manner than local suppliers. $22.2 \%$ respondents also hinted that their bank sometimes introduces buyers to procure their wares thereby helping them to sell their goods. 18.5\% respondents also indicated that they attend workshops organized by government agencies and other NGO to shore up their managerial capacity. $24.1 \%$ respondents pointed out that through their bank's efforts they are able to buy in big quantities at huge discounts that bring about level of profits.

\section{Discussion of Findings}

All respondents $(100 \%)$ agreed with the suggestion that Universal Merchant Banks in the country offer overdraft facilities: personal loans, corporate loans, SME loans, leasing facilities, agricultural enhancement loans, collateral management, project financing and mortgage loans services to its various categories of customers. This finding has been supported in various kinds of literature in this domain. Writers like Hester and Pierce (2002), Morsman (2003) and Shapiro (2006) all explained that universal and commercial banks together offer similar products in order to survive in the industry. Banks will like to see their profit as one stock bank where all banking products and services can be accessed. In such circumstances, survival depends upon the quality of service and affordability of service charges.

From the study, large segment of the respondents mentioned the reasons for banks declining loan applications to stretch from poor track record of applicants, insufficient profit to accommodate repayment of facility and attendant interest to inadequate collateral security and poor supporting documents especially management account and Finance Statements. Rodriguez and Carter (2004) also added that SMEs have poor credit rating in that, they hardly save and therefore cannot fall on any tangible financial assets to back their loan applications.

Asiedu-Mante (2006) also indicated that, a good number of SMEs do not conduct proper assessment of their business prospect prior to approaching their bankers for support of their business proposals. Dyer (2004) found out that a sizeable number of SMEs deceives banks with incorrect financial information to contract loans which are invariably diverted for other purposes. This source mentioned categorically information asymmetry as a huge problem that stakeholders will have to address if the banks are to easily supply funds for small business operators to expand their business horizon.

On internal reasons for customers defaulting on loan repayment schedule $87.6 \%$ of bank respondents noted such factors as diversion of funds meant for business expansion, diversification of business lines without prior discussion with the bank, modernization of business with short-term loans rather than long-term loans and taking up new projects which have not been approved by the bank. Other internal defaulting factors are helping to promote associated business, time or cost overrun during the implementation of projects, failure of market or product management inefficiency, slackness in credit management and monitoring, inappropriate technology or technical problems and lack of co-ordination among lenders. 
Essien (2005) castigated SMEs in his study or similar subject and explained further that majority of loans contracted by small businesses are often diverted and that until this practice is stopped the banks will continue to discriminate against small business in their loan portfolio investments. Hester (2001) also made additional finding to this problem and pointed out that some bank officials detailed to monitor and control loans on the field are not helping matters because they often accept gifts which usually compromise their professional positions thereby painting a wrong picture of the real situation on the ground to their superior officers.

On his part, Kotler (2007) noted that sometimes customers are not given the right explanation as to why short-term loans ought not to be used to procure long-term purchases. Such vital information emanating from the bank and other service providers will go a long way to help minimize high incidence non-performing loans. With respect to the objective on challenges of managing credit risk at UMB, 78\% respondents mentioned logistical constraints such as vehicles; customers complaint of poor market and management interferences. Adu-Mante (2007) supported this view and expressed concerns over the high incidence of dumped cheap Chinese products on the Ghanaian market which force patrons to switch allegiance from traditional products to Chinese products most of which are nearing expiry dates. Thompson and Strickland (2007) also saw the importance of putting in place the right kind of infrastructure especially vehicles to enhance loan monitoring and controlling purposes. On his part, Dyer (2004 noted that in some developing economies, senior managers of banks assist their relatives in accessing loans and when they have challenges in repayment, then loan officers are influenced to bend the rule to suit these relation borrowers. The source therefore stresses the need for financial institutions to establish strong guidelines restricting bank officials from aiding friends and relatives in accessing loans. On strategies for improving credit risk management at Universal Merchant Bank, $82 \%$ respondents mentioned making credit officers responsible for full recovery of loans, day to day monitoring as well as cash picking arrangements with the customers. These findings were also contained in articles featured by Dyer (2004) and Mwaneketwe (2007). Dyer (2004) explained that banks should divide means of going to the field to pick up funds from small business owners as a way of minimizing default on loan repayment schedule. The source noted that having gotten enough revenue from sales, some small business owners feel reluctant in walking up to the bank to pay for amount owed by way of loans contracted. Meeting the customer on the field therefore provides a very viable option for retrieving loans thereby minimizing bad debt and improving upon credit risk management skills.

\section{Conclusion}

The study examined the high-risk factors associated with financing SMEs in Ghana and noted that although SMEs constitute the engine of growth in the Ghanaian economy and therefore ought to be financially fluid, banks often sustain serious financial injuries in the process of providing the badly needed funds. Numerous challenges associated with financing SMEs in Ghana stretch from deliberate efforts at misapplying solicited short-term funds for capital expenditure such as buying land or vehicles which eventually resulting repayment challenges The study noted with surprise that unfair trade practices especially dumping of cheap Chinese products on the local market also result in poor sales for the SMEs leading to difficulty in honoring structured loan repayment schedules. Generally, SMEs ought to be sensitized through periodic capacity building packages so as to enable them wield basic knowledge in financial management, marketing management as well as banking operations 
so as to enable them apply loans contracted judiciously. Central government of Ghana should support alternative channels through which longer-term soft loans can be secured to enable SMEs finance their operations properly thereby being in a better position to strengthen the engine of growth of the economy. SMEs are really a force to reckon within the socioeconomic development of the country and therefore stakeholders must wake up to the occasion and help them to thrive.

\section{Recommendations}

Based on the findings and challenges discussed above; the following are recommended:

\section{Building Capacity of SMEs to Minimizes Credit Risk}

The study uncovered that, most of the huge bad debts sticking in the books of the banks emanated from their association with SMEs. Consequently, it is recommended that government should help banks and stakeholder NGOs to organize more capacity building workshops for SMEs so as sharpened their financial management skills, marketing and pricing strategies, etc, thereby minimizing risk factors associated with loan investment made to this sector.

\section{Expanding Access to other forms of Finance}

It appears that business houses are relying too heavily on bank credits and since most of them are unable to produce the required collaterals for attracting loans, they often do not receive such facilities to enhance their businesses. It is hereby recommended that information on established Government's Venture Capital Trust fund should be made more accessible to the SMEs sectors through government sponsored workshops whilst the capacity and logistics of the Exim-guaranty Limited are strengthened to enable more small scale enterprises to obtain funding without the need to produce collateral security. With more businesses coming on board, banks are likely to mobilize more cheap loans thereby enabling them to increase loan exposure to this sector.

\section{Government and Institutional Support for Business Community}

To enable the informal business sectors to perform their role effectively, technical, institutional and financial supports must be put in place by government to address all the weaknesses and challenges faced by these groups. This will help ease pressure on bank loans so as to grant credit analysts adequate time to properly appraise loan proposals for manageable size of customers. This can be done through a national policy including financing strategies to be formulated by the government under the auspices of the Bank of Ghana with the participation of other financial institutions to make loans easily accessible to SMEs. This would harness additional funds from financial institutions thereby creating a much larger pool of resources for loans to the SMEs. Government through the central Bank must formulate clear, definite and positive financing policies for implementation by all banks. Priority or profitable sectors may be designated. Special incentives may be extended to financial institutions, which lend to the sector.

\section{Decentralizing Credit Analysis Machinery}

The study uncovered the fact that, most of the banks have centralized their credit appraisal functions and that branch officers only act as conduits through which customers documents are routed to the corporate centre in Accra for analysis. This is not only reprehensible but also totally unacceptable. Though the intention might sound good i.e. ensuring that 
experienced credit analysts handle loan proposals, it will equally be useful if not more purposefully for banks to train or engage more credit analysts who will be stationed at the various branches to administer loans up to a particular limit. This will also go a very long way to enhance monitoring and controlling of loan disburses at that branch level.

5. Addressing the issues of dumping of International Goods and loan Default

The study revealed further that SMEs are not insulated from international competition, and many SMEs admitted that they are now faced with greater external competition emanating from the importation of much cheaper products from China and India. It is therefore recommended that the ministry of trade and industries as well as foreign affairs must collaborate and strategize on ways of helping local small and medium businesses out of this crisis. If this entails raising import duty on such cheap products, then appropriated state agency must go ahead to ensure that foreign products do not kill local businesses thereby weakening the ability of the SME borrowers to honour their loan responsibilities.

\section{Managerial Challenges}

Although some of the leading banks are helping to improve the managerial skills of the SME sector, entrepreneurs should be encouraged to participate in business-oriented seminars to sharpen their skills. The findings that, an appreciable number of respondents wield tertiary qualification presupposes that given the right business aptitude in training, most of the credit risk problems will be reduced so as to minimize the incidence of bad debt or non-performing assets.

\section{Research Limitation and Future Directions}

The outcome and results of this study is not free from a set of inherent limitations. The study was basically limited in scope and methodology. Firstly, commercial banks in Ghana are experiencing challenges with credit risk management leading to very high industry average for debt to loan ratio. Therefore, using only UMB, in such an important study meant that there was insufficient sample for the statistical measurement. Secondly, there was limited access to data (bad debt) of customers due to the data been considered as a classified information, leading to a limited scope of discussion for the study. Resource mobilization for this study in the face of COVID-19 was difficult and almost impossible to carry through within the limited time. In the face of all these challenges, the researchers were determined to complete this study within the time frame with the limited resource available. Based on the limitations of scope and methodology, the researchers suggest a future study that covers sufficient sample size, and access to available data across banks operating in Ghana for a wider scope for discussion and statistical analysis. A qualitative study should be considered to understand into details and unmasked the reasons behind the bad debt portfolios of more than eight (8) commercial banks that collapsed in the year 2020.

\section{References}

Addaih, S. (2008). Need to nurture small scale entrepreneurs at community levels. Daily Graphic, Print Newspaper Volume.150451, p33.

Adu-Mante, L. (2007). GCB pumps US\$ 27.9 million into SMEs. Commerbank News, Print Newspaper 6.

Agiobenebo T. J., \& Ezirim, C. B (2003). Impact of financial intermediation on the profitability of insurance companies in Nigeria. First Bank Quarterly Review, 2003 March - pp. 20-31 
Aku, Victor (2008) "Developing small scale enterprises as engine for local economic growth" Ghanaian Times of Wednesday 13, $2008 \mathrm{p} 9$.

Allen, F. \& Santomero, A. (1997). The theory of financial intermediation. Journal of Banking and Finance.

Amissah Arthur, K. B. (2012). The role of the banking sector in developing the ghanaian capital market. Address by, Governor, Bank of Ghana on the theme: Financing Ghana's Future Capital Markets.

Anam, S., Hasan, S. B., Huda, H. A. E., Uddin, A., \& Hossain, M. M. (2012). "Liquidity risk management: a comparative study between conventional and Islamic Banks of Bangladesh", Research Journal of Economics, Business and ICT, 5, 1-5.

Andrew, W. M. \& Victor, M (2003). Handbook of International Banking, Published by Edward Elgar Publishing Limited, pages 207- 637.

Aryeetey, E.; Asanti, E.; Kyei, A. \& Gockel .F. (2002), Mobilizing Domestic Savings for African Development and Diversification: A Ghanaian Case-Study, Research Report Presented at a workshop on Domestic Resource Mobilization at the International Development Center, Queen Elizabeth House, University of Oxford, 16-20/7/90.

Asiedu-Mante, E. (2006) "Expand the scope of the Banking sector" (Daily Graphic of August, 5, 2006) p. 29

Augusto de la Torre, M., Soledad M. P. and Sergio L. S. (2008) on Bank Involvement with SMEs: Beyond Relationship Lending, March, Journal of Finance

Bank of Ghana Policy Brief (2006),"Financing SMEs in Ghana: The Need for Market Oriented Interventions".

Bank of Ghana (2012) "Financial Stability Report", Volume 4, No. 2/2012

Bank of Ghana, (2007), A Not on Microfinance in Ghana, Working Paper WP /BOG-2007/01, Bank of Ghana Research Department.

Berger, A. \& Udell, G. (1995) "Relationship Lending and Lines of Credit in Small Firm Finance," Journal of Business, July, Vol. 19, pp 23-34

Berlin, M., and L. J. Meste (1999). Deposits and relationship lending. Review of Financial Studies, 12(3), 579-607

Bhattacharya, S. \& Thakor, A. (2003). Contemporary banking theory. Journal of Financial Intermediation. Pp. 12-15

Briham, E., F \& Ehrhardt M. C. (2003) Financial management: theory and practice. Thomson South Western publishing, pp.770

Bucks, H. \& Johan, M. (2005). Competition and efficiency in banking: behavioral evidence from Ghana. International Monetary Fund (IMF) working Paper WP/05/17.

Calomiris, C. W. (1995). Universal banking and the financing of Industrial Development. World Bank Policy Research Working paper No. 1533, Columbia Business School

Chen, K. \& Pan, C. (2012). An empirical study of credit risk efficiency of banking industry in Taiwan, Web Journal of Chinese Management Review, 15(1), 1-16

Colvin, Louis Christopher (2007), Universal banking Failure? An analysis of the contrasting responses of the Amsterdamsche Bank and the RotterdamscheBankvereeniging to the Dutch Financial Crisis of the 1920s. London School of Economics. Working papers No. 98/07. March, 2007

Conti, C. \& Mauri, A. (2008). Corporate financial risk management: governance and disclosure post IFRS 7. Icfai Journal of Financial Risk Management,2, pp.20-27.

Demirgüç-Kunt, A. (2011). Small medium enterprises finance: The real challenge" Journal of Financial Services Research, pp.18-38

Dermine, J., \& Youssef .F. B. (2007) Asset and liability management: the banker's guide to value creation and risk control. $2^{\text {nd }}$ ed. Harlow, UK: FT Prentice Hall.

Derreumaux, P (2007). The difficulties banks face in financing SMEs in Sub-Saharan Africa (SSA): Who is to blame?, Proparco's magazine, 1 May, pp. 19-21

Diamond, S. (2001). Debt Maturity Structure and Liquidity Risk," Quarterly Journal of Economics, CVI, 709-738. 
Dyer, L. S. (2005). Advance lending techniques, London: Institute of Bankers Publications

Edwards J. \& Millet .L. (2002) Accountancy for Bankers. Chartered Institute of Bankers publications Studies, 12(3), 579-607

Essien, A. (2005). Contemporary forms of financing business organizations, a workshop organized by UT Bank for Captains of Industry. Vol. 11, pp. 10-12

Ezirim, C.B. (2007). Should the Investment Banking and Corporate Finance Spirit of Merchant Banks be Exorcised from the Nigerian Banking system? Journal of Sustainable Development in Africa Vol.9, No. 2; Fayetteville State University, North Carolina.

Fallon, W. (1996). Calculating Value-at-Risk. Working Paper 96-49, Wharton Financial Institutions Center, The Wharton School, University of Pennsylvania.

Froot, K., D. Scharfstein, \& J. Stein, (2003). Risk Management: Coordinating Investment and Financing Policies. Journal of Finance, December

Furash, E., (1994). Organizing the Risk Management Process In Large Banks," Risk Management Planning Seminar, Federal Financial Institutions Examination Council, Washington, D.C., September 29.

Gelb J., B. \& Gelb, D. (1999) "Predicting cooperative behaviour during a retailer's bankruptcy", Qualitative Market Research: An International Journal,2(1), pp.31 - 45

George M. Gloria K. \& Bob-Miller, (2007). Developments in the Banking Sector Ghana Banking Survey 2008, Price Water House Coopers in association with Ghana Association of Bankers.30, April 2007.

Ghana Statistical Service (2008). Ghana living standards survey: Report of the Fifth round. Accra: Ghana Statistical Service.

Gorrod, M. (2004) Risk management systems: technology trends (Finance and Capital Markets). Basingstoke: Palgrave Macmillan.

Havrilesky, T. and Boorman, J. (2001) Current Perspectives in Banking, Arlington Heights, Ill: AHM Publishing Corporation

Henderson, N. R (2007) “The Power of Probing” Marketing Research,19(4).

Hester, D. \& Pierce, J. (2002). Bank Management and Portfolio Behaviour. New Haven: Yale University Press.

Hester, D. (2001). Innovations and Monetary control, Brooking Papers on Economic Activity pp 146-173.

Hodgman, D. (2001). Commercial Bank Loan and Investment Policy Urban, Ill: Illinois. University of Illinois Press.

Jorion, P., (2007). Value at Risk: The New Benchmark for Control Market Risk, Irwin Professional Publications, Illinois.

Kashyap, A. K; Raghuram, R. and Stein J. C (2002). Banks as Liquidity Providers: An Explanation for the Coexistence of Lending and Deposit-Taking", Journal of Finance, American Finance Association, vol. 57(1), pp 33-73.

Kim, D. and Santomero, A. (2003). Forecasting Required Loan Loss Reserves," Journal of Economics and Business, August.

Kothari, C.R. (2004). Research Methodology Methods and Techniques. New Age International (P) Limited: New Delhi.

Kotler P. (2007). Marketing management. $12^{\text {th }}$ Ed Pearson, Prentice Hall Publishers, New Jersey.

Long staff, P., \& Schwartz, E. (1995). A Simple Approach to Valuing Risky Fixed and floating Rate Debt. Journal of Finance, Vol.5pp789-819

Madura, J. (2008). Financial institutions and markets. 8th Ed Thomson Southwestern Publishers.

Mankiw. G. (2001). Small menu costs and large business cycles: a macroeconomic model of monopoly," Quarterly Journal of Economics, vol. 100, May, pp. 529-537.

Markowitz H.M (1952). Portfolio selection. Journal of Finance, Vol. 7 nol.

Mayer, M. (2002). The Bankers. $5^{\text {th }}$ Ed. New York: Balantine Books

Mensah, S (2004). A Review of SME Financing in Ghana. Presented at the UNIDO Regional workshop of financing SMEs, Accra, Ghana in March 2. 
Morsman, E. (2003). Commercial Loan Portfolio Management. Philadelphia: Robert Morris Associates.

Mwanakatwe, M.(2007). Barclays Support for SME's" Daily Graphic vol. 150064 of June 12 2007, p 10.

Narasimhan, C.R.L (2002). Universal Banking: The Means and the Ends Are Controversial; published by the HINDU, Online Edition of India's National Newspaper. Vol. No. 18 pp. $36-42$

Oldfield, G. \& Santomero, A. (2007). The place of risk management in financial institutions. Sloan Management Review, Summer forthcoming.

O'Leary, Z. (2014). The essential guide to doing your research project. Los Angeles, CA: Sage.

Osaafo-Maafo Y. (2004). SMEs not taking advantage of institutional interventions. Ghana: daily graphic, vol. 140968 of march 18, 2004. Pg 28.

Otabil, B. (2008). Nigerian banks find doing business in Ghana good to resist. Daily Graphic, June 19 ,

Phelan, M. (2007). Probability and statistics applied to the practice of financial risk management: The Case of JP Morgan's Risk Metrics TM. Journal of Financial Services Research, June, Vol. 20, pp. 45-68

Raghuram, R. \& Wulf, J., (2003). The flattening firm: evidence from panel data on the changing nature of corporate hierarchies. Review of Economics and Statistics 82, 591-629.

Robinson, M. (2001). The Microfinance Revolution: Sustainable Finance ForThe Poor. Washington DC: World bank.

Rodriguez, R. M, \& Carter, E. E. (2004) International financial management . Englewood Cliffs, New Jersey: Prentice-Hall, Inc.

Rouse, N. (2004) Applied lending techniques. London: The Chartered Institute of Bankers Publication

Salomon Brothers, (1993) Bankers trust New York Corporation - Risk Management. United States Equity Research, February

Saunders, A. (1996). Financial institutions management: A modern perspective. Irwin Publishers, Illinois.

Shapiro A. C. (2002). Risk in international banking. Journal of finance vol. 1324, pp. 36-45

Silber, W. (2008). Commercial Bank Liability Management, Chicago: Association of Reserve city Bankers.

Smith, C., Smithson, C. and Wilford, D. (1990). Strategic Risk Management: (Institutional Investor Series in Finance), New York: Harper and Row.

Sproul, M. (1998). The quantity theory versus the Real Bills Doctrine in Colonial America. In Economics Working Papers.

Strauss, A. \& J. Corbin (2000) Basic qualitative research, Sage Publications: Newbury Park, CA.

Tapiero, C., (2004) Risk and Financial Management: Mathematical and Computational Methods. John Wiley \& Son.

Thompson A. \& Strickland A. J. (2007). Strategic Management; Concept and Cases. 9th Edition. Mcgraw-Hill Inc.

Tilman, L. M. (2003). Asset liability management of financial institutions: maximizing shareholder value through risk-conscious investing. London: Euro money.

Wee, L. \& Lee, J., (1995). RAROC and risk management quantifying the risks of business. Bankers Trust New York Corporation. Pp 11-19

Winsome, J \& Johnson, S. (2000). The pros and cons of data analysis software for qualitative research. Journal of Nursing Scholarship 32(4), pp 393-397

Zikmund, W. \& Babin, B. (2010). Exploring marketing research $\left(10^{\text {th }}\right.$ ed.) South-Western Cengage Learning Pp 188-186. 